Vol. 37(2), pp. 137-154, Dec. 2018

ISSN 1821-536X (print)

ISSN 2619-8789 (electronic)
Tanzania Journal of Engineering and Technology Copyright (c) 2018 College of Engineering and

Technology, University of Dar es Salaam

Full Length Research Paper

Creative commons licence type CC BY-NC-ND

\title{
The Fate of Nitrogen and Faecal Coliform in the Lubigi Wetland in Uganda
}

\author{
John K. Kayima ${ }^{1 *}$, Aloyce W. Mayo ${ }^{2}$ and Joel K. Nobert ${ }^{2}$ \\ ${ }^{1}$ Engiplan Consultants, Plot 697, Kitakule/Bishop Crescent off Balintuma Road, \\ P. O. Box 3504, Kampala, Uganda. \\ ${ }^{2}$ Department of Water Resources Engineering, University of Dar es Salaam, \\ P.O. Box 35131, Dar es Salaam, Tanzania. E-mail: aloyce.mayo@yahoo.com \\ *Corresponding author: engiplancon@yahoo.com
}

\begin{abstract}
The capacity of the Lubigi wetland to reduce nitrogen and faecal coliform pollution entering Lake Kyoga in Uganda was investigated. Three transects with 5 sampling points in each, were established in the wetland. Wetland plants samples were collected from the specific locations along the transects, and laboratory tests and analyses were carried out for plants biomass and nitrogen contents determination. Samples of wetland sediments were also collected, and laboratory tests and analyses were done for determination of nitrogen content in the sediments. Wetland water samples were taken from the main wetland inlet and the main outlet from the wetland main study area. At the same time, wetland water $\mathrm{pH}$, dissolved oxygen and temperatures were measured in-situ. Laboratory tests and analyses for ammonia-nitrogen, nitrate-nitrogen, total Kjeldahl nitrogen, total nitrogen and faecal coliforms were carried out on the wetland water samples. The results indicate that the Lubigi wetland received about 16 to $173 \mathrm{mg} / \mathrm{l}$ of total nitrogen, largely in form of organicnitrogen (64.7\%) and ammonia-nitrogen (35.2\%). Nitrate-nitrogen and Nitrite-nitrite accounted for only $0.1 \%$ of the total nitrogen in the inlet. The wetland removed about $24.9 \%$ of this nitrogen, which is equivalent to removal of about 1,672 tons of nitrogen annually. About $67.5 \mathrm{gN} / \mathrm{m}^{2}$ and $0.30 \mathrm{gN} / \mathrm{kg}$ of dry sediments were sequestered in the wetland plants biomass and the benthic layer respectively. The Lubigi wetland main study area also receives faecal coliform concentrations with the wetland inlet mean value of 653,509 CFU/100ml and its outlet mean value is 218,676 CFU/100ml. These values give a faecal coliform (FC) overall removal efficiency of approximately $66.5 \%$. It was thus concluded that the Lubigi wetland has considerable capacity to buffer and protect Lake Kyoga, by reducing nitrogen and faecal coliform pollution entering the lake.
\end{abstract}

Key words: Faecal coliform pollution, Lubigi wetland, Nitrogen removal.

\section{INTRODUCTION}

The Lubigi wetland, which is located in the north-western part of Kampala, is one of the largest Lake Kyoga drainage basin wetlands (Kayima and Mayo, 2018). The wetland receives discharges from a canalized stream and the Nsooba-Lubigi drainage channel with an average capacity of approximately $220,000 \mathrm{~m}^{3} /$ day. The channel collects municipal and industrial wastewater, storm water run-off and subsurface water flow from the upstream densely populated and unsewered slums. In addition, the stream receives effluent discharges from the Lubigi sewage 
treatment plant, with a design capacity of $5,400 \mathrm{~m}^{3} /$ day (Watebawa, 2012; National Water and Sewerage Corporation, 2015). Therefore this wetland is practically used for disposal of municipal wastewater (Kayima et al., 2018a).

Natural wetlands, Lubigi inclusive, have capacities to remove toxins and nutrients from water bodies (Marwa, 2013; Kayima et al., 2018a; Masawe et al., 2018). Therefore they act as ecological transition zones that protect the quality of water in downstream fresh water bodies such as rivers and lakes (Terer et al., 2005; Henry and Semili, 2005; Mayo et al., 2018). At present, there are serious concerns that the Lubigi wetland will not only become degraded, but will also pass on pollutants from upstream discharges, to the downstream fresh water bodies of the Mayanja River and Lake Kyoga (Kayima et al., 2018). This could lead to excessive concentrations of, among other pollutants, nitrogen and faecal coliforms (FC) (Kayima et al., 2018) leading to serious problems for people who rely on these water bodies for various uses (Gumm, 2011).

Nitrogen is among the major pollutants found in raw or partially treated wastewater (Metcalf and Eddy Inc., 2003). Excessive concentrations of nitrogen can stimulate eutrophication (Bricker et al., 2008), which can lead to production of greenhouse gases (Kinney and Valiela, 2013), blockages of receiving fresh water bodies, and interference with navigation (UNEP, 2013). The exposure to excessive concentration of ammonia can lead to toxicity to aquatic life and depletion of dissolved oxygen, which can cause the death of fish, damage coral reefs and render water septic and odorous and therefore unfit for human and animal use (Morrow, 2009; Baker et al., 2013; Li et al., 2014; Shin et al., 2016). Excessive nitrate in drinking water is known to cause methamoglobinaemia (blue baby disease) in infants and increased cancer risks in human beings (Senzia, 2003; Rogan and Brady, 2009; Karr, 2012; Brender et al., 2013). On the other hand, pathogenic organisms present in wastewater can cause diseases and severe public health problems, and are considered to be responsible for most of the morbidity and mortality in developing countries (WHO, 2015).

Wetlands are not only effective for removal of chemical pollutants, but they are also effective in reduction of pathogens (Mayo and Kalibbala, 2007; Kalibbala et al., 2008), which is vital for protection of human health against diseases. However, the knowledge on the fate and removal of bacteria in wetlands is still unclear owing to the complexity of influencing factors and bacterial removal mechanisms (Weber and Legge, 2008; Wu et al., 2016). Wetlands receive bacterial pollution from multiple sources including inlet wastewater and animals that live in or around the wetland. Their performance is also highly dependent on the type and density of macrophytes, hydrology, hydraulic regime, retention time and various physical-chemical factors that influence natural die-off of bacteria (Kalibbala et al., 2008; Weber and Legge, 2008).

While it is known that wetlands receiving wastewater have capacities to transform and remove the pollutants contained in the wastewater (Mitsch and Gosselink, 2007; Bavor and Waters, 2008; Mayo et al., 2014), the performance of wetlands differ because of aforementioned factors. Therefore, it is important to investigate the fate of nitrogen and faecal coliforms in the Lubigi wetland, with a view to assessing the capacity of the wetland to reduce nitrogen and faecal coliform pollution entering the downstream Mayanja River and Lake Kyoga. To achieve this objective, it was necessary to investigate the effectiveness of Lubigi wetland in 
reduction of nitrogen and faecal bacteria, which is the main objective of this research study.

\section{MATERIALS AND METHODS}

\section{The Main Study Area}

Figure 1 shows the main study area, which is delineated in the north-east of Kampala city by the Hoima Road, with the main wastewater inlet located at latitude $00^{\circ} 20^{\prime} 48^{\prime \prime} \mathrm{N}$ and longitude $32^{\circ} 32^{\prime} 28^{\prime \prime} \mathrm{E}$; and in the south-west by the Sentema Road with the main wetland outlets located at latitude $00^{\circ} 19^{\prime} 56^{\prime \prime} \mathrm{N}$ and longitude $32^{\circ} 31^{\prime} 34$ " E. This section of the wetland covers an area of about $1.1 \mathrm{~km}^{2}$, at an altitude of approximately $1,158 \mathrm{~m}$ above sea level, with a total catchment area of about $40 \mathrm{~km}^{2}$. This is the section of the wetland, which receives direct impact of polluted wastewater from upstream sources. This zone is closest to the wetland main wastewater inlet and is dominated by Echinochloa pyramidalis and Paspalum scrobiculatum, with abundance of other assorted types of plant species. Hence, transect T1 was established in this section about $700 \mathrm{~m}$ downstream of the wetland main wastewater inlet. The middle zone was observed to be dominated by Cyperus papyrus and Typha capensis, with abundance of other assorted types of plant species. Hence, transect T2 was established in this section about $1,440 \mathrm{~m}$ downstream of the wetland main wastewater inlet. The zone closest to the main study area outlets was observed to be dominated by Cyperus papyrus and Thelypteris acuminata, with abundance of other assorted types of plant species. Hence, transect T3 was established in this section about $1,930 \mathrm{~m}$ downstream of the wetland main wastewater inlet (Figure 1).

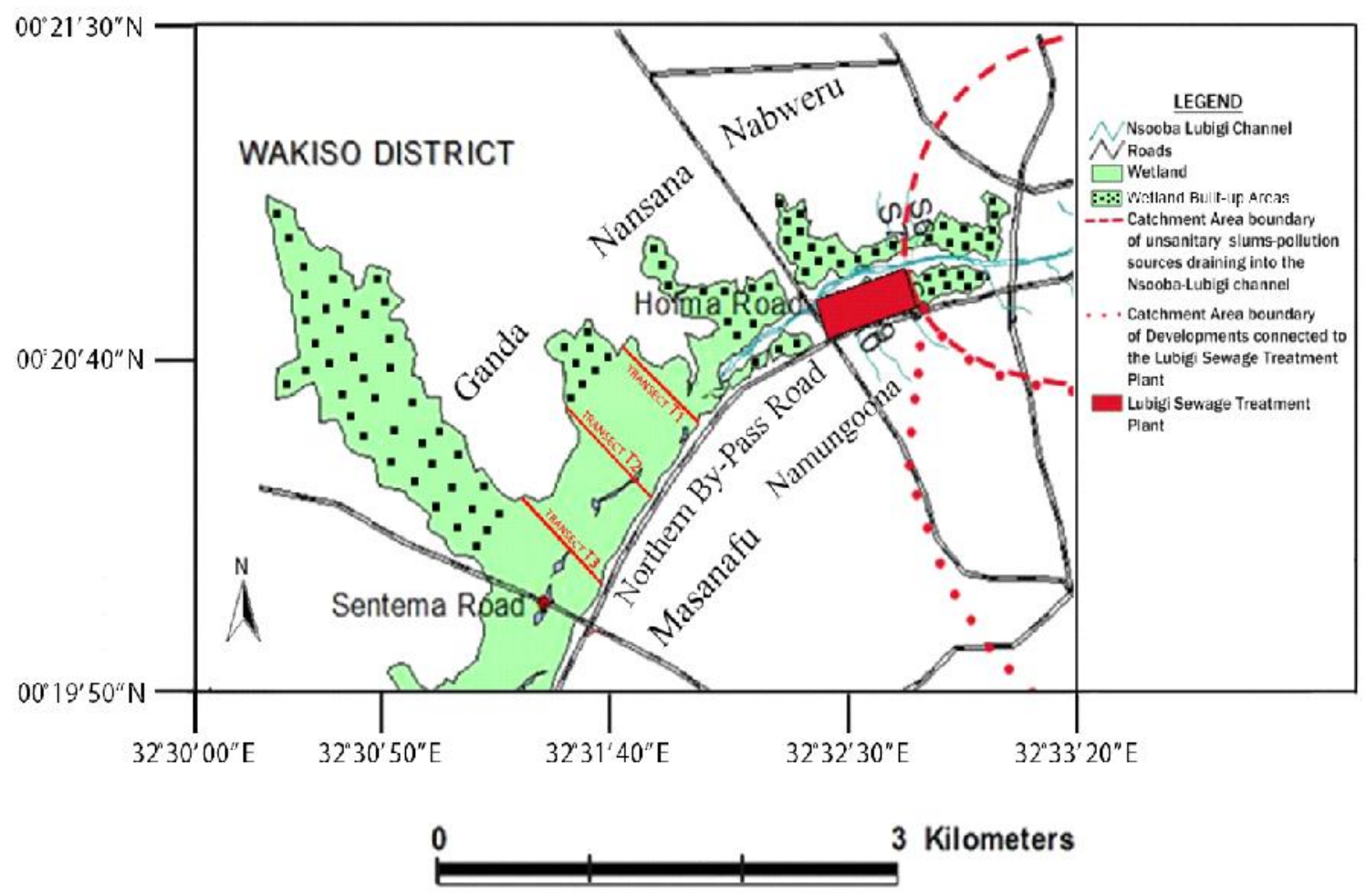

Figure 1: Map of the Lubigi Wetland Main Study Area

In each of the 3 transects, 5 sampling points were established in order to closely follow the spatial variability across the widths of the wetland, as one moves from 
the main central drainage channel away towards the edges of the wetland on either side of the channel. The transects and sampling points were geo-referenced using a Garmin Global Positioning System (GPS) device, in order to determine and record the co-ordinates of their locations. Then they were transferred to a digitized map of the area, to ensure that the same transects and points are used every time sampling is done. To facilitate movements and work within the transects, Cyperus papyrus culms were cut and tied in bundles which were laid down to make accessible paths. Life rafts and jackets and other safety precautions and measures, were used throughout the research field work.

\section{Field and Laboratory Tests}

\section{Determination of plants biomass}

The sampling of plants for biomass determination was done in October and November 2016. The 5 most dominant plants species namely Cyperus papyrus, Echinochloa pyramidalis, Typha capensis, Rottboellia cochinchinensis and Oldenlandia lancifolia were analyzed. These most dominant plant species were harvested; from the already established $1 \mathrm{~m} \times 1 \mathrm{~m}$ sampling quadrats in transects $\mathrm{T} 1$, $\mathrm{T} 2$ and $\mathrm{T} 3$. The above-ground biomass was cut and separated into leaves/umbels and stalks/culms depending on the plant type. Then these parts were weighed using a digital balance in the field, in order to obtain the total wet weight of each plant part. The below-ground biomass was removed by digging up all roots/rhizomes in the $1 \mathrm{mx} 1 \mathrm{~m}$ quadrats, and carefully washing off all the dead materials and soil/peat. The roots/rhizomes were also weighed in the field, in order to obtain their total wet weight. From the whole sample of each plant part in a $1 \mathrm{mx} 1 \mathrm{~m}$ quadrat, a sub-sample weighing $500 \mathrm{~g}$ was taken for sun-drying in the Makerere University Plant Sciences, Microbiology and Biotechnology laboratory, in Uganda. The sun-dried samples of each plant part were thereafter oven-dried at $105{ }^{\circ} \mathrm{C}$. The dry weight to wet weight ratio of the $500 \mathrm{~g}$ sub-sample, was used to calculate the total dry weight in the $1 \mathrm{mx} 1 \mathrm{~m}$ quadrats in the transects.

\section{Determination of nitrogen content in the plants}

Total-nitrogen (TN) was chosen as the basic element for nitrogen used up by plants. The total-nitrogen content of the dried plant parts was determined according to the methods used by Novozamsky et al. (1983). Fine materials out of every plant part were obtained by grinding a portion of the dried plant parts in a manual grinder. Then the fine materials were sieved through a $0.5 \mathrm{~mm}$ sieve in the Kawanda National Agricultural Research Organization laboratory in Uganda, and the ensuing powder was preserved following the preparation methodology devised by Muthuri and Jones (1997).

Thereafter, portions of the dried powder were scooped up, and transferred quantitatively into the destruction tubes in which digestion was done in a block, using a concentrated Sulphuric-salicylic mixture with Selenium as a catalyst. The analysis of total nitrogen in the digested samples was then carried out, in accordance with the Standard Methods for the Examination of Water and Wastewater (APHA et al., 2012). Finally, nitrogen content in plants was determined following the approach described by Muraza (2013). In this approach, the plants biomass content in kilograms of plants dry weight per square meter of wetland $\left(\mathrm{kgDWm}^{-2}\right)$, and the plants nitrogen content as a percentage of plants Dry Weight (\%DW) were first determined. Then the plants nitrogen content in $\mathrm{g} \mathrm{N} . \mathrm{m}^{-2}$ was determined as the product of the plants biomass content and the plants nitrogen content as a percentage. 


\section{Determination of nitrogen content in the sediments}

The collection of wetland sediments was done simultaneously with the plants sampling. The sediments were collected from 3 of the 5 sampling quadrats, in each of the 3 transects T1, T2 and T3. The sediments samples were packed in cool boxes and transported to the Makerere University Plant Sciences, Microbiology and Biotechnology laboratory in Uganda, where they were-oven dried at $105{ }^{\circ} \mathrm{C}$. After drying, the samples were ground in a manual grinder and sieved through a 0.5 $\mathrm{mm}$ sieve size in the Kawanda National Agricultural Research Organization laboratory in Uganda, in order to obtain the dry powder.

To analyze the sediments for nitrogen contents, sub-samples of appropriate weights were taken and digested in a block, using a concentrated Sulphuricsalicylic mixture with Selenium as a catalyst. The analysis of nitrogen in the digested samples was then carried out following the total nitrogen determination procedures, in accordance with the Standard Methods for the Examination of Water and Wastewater samples (APHA et al., 2012). The determination of the nitrogen content in the sediments in $\mathrm{gm}^{-2}$, was done by multiplying the sediments nitrogen content in grams of nitrogen per kilogram of sediments by the density of sediments in $\mathrm{kgm}^{-3}$ and then by $0.5 \mathrm{~m}$. This was based on the consideration that the effective sediments depth for nitrogen sedimentation is $0.5 \mathrm{~m}$. At depths in the sediments exceeding $0.5 \mathrm{~m}$, layers of stiff and almost impermeable clay soils are encountered in the wetland.

\section{Determination of wetland water characteristics}

Seventy two (72) wetland water samples were collected at bi-weekly intervals from August 2016 to February 2018 inclusive, from the main wetland inlet and the main wetland outlet. Samples of 2.0 liters each were collected from a depth of $10 \mathrm{~cm}$ to 20 $\mathrm{cm}$ below the water surface, into sterilized plastic containers. The samples were stored in cool boxes, and then transported to the National Water and Sewerage Corporation laboratory in Uganda, and examined within a period of 4 hours. At the same time, in situ wetland water temperatures were measured with portable thermometer WTW 3310. The $\mathrm{pH}$ values were measured with a $\mathrm{pH}$ electrode SenTix 21 WTW, connected to a portable $\mathrm{pH}$ meter WTW 3310. Dissolved oxygen (DO) was measured with a dissolved oxygen electrode CellOx 325 WTW, connected to a portable DO meter WTW 3310.

Laboratory tests and analyses for ammonia-nitrogen $\left(\mathrm{NH}_{3}-\mathrm{N}\right), \quad$ nitritenitrogen $\left(\mathrm{NO}_{2}-\mathrm{N}\right)$, nitrate-nitrogen $\left(\mathrm{NO}_{3}{ }^{-}\right.$ $\mathrm{N})$, Total Kjeldahl Nitrogen (TKN), Total Nitrogen (TN) and faecal coliforms (FC) were carried out on the wetland water samples, in accordance with the standard methods for the examination of water and wastewater (APHA et al., 2012). Wetland water samples were kept under refrigeration at about $4{ }^{\circ} \mathrm{C}$ during storage. Chemical preservation was done by adding $1 \mathrm{ml}$ of sulphuric acid $\left(\mathrm{H}_{2} \mathrm{SO}_{4}\right)$ to 1 liter of the sample to achieve a $\mathrm{pH}$ below 2 for preservation of samples for determination of ammonia-nitrogen. Ammonia-nitrogen was analyzed using the Turbidmetric method, and the Nessler reagent. Nitratenitrogen $\left(\mathrm{NO}_{3}-\mathrm{N}\right)$ was analyzed using the Spectrophotometer with Cadmium method, and the Nitra Version 5 reagent. TKN was analyzed using the Semi-Micro Kjeldahl method. The organic-nitrogen (Org-N) was determined by calculating the difference between TKN and ammonianitrogen. Faecal coliforms were enumerated using membrane filtration technique using M-FC agar base solution as the medium in accordance with Standard methods for the examination of 
water and wastewater samples (APHA et al., 2012).

\section{Data processing}

All data generated in this research study were preliminarily examined to check for their correctness. Those found to be obviously erroneous, by virtue of appearing to be incongruous with the rest of the data in their respective sets, were discarded. Subsequently, Microsoft EXCEL 2008 spreadsheet and MINITAB Release 15 for Windows software were used to analyze the remaining data. The Anderson-Darling test was used for testing normality. Comparisons of variables were performed using the Analysis of Variances (ANOVA) technique. Multiple comparisons were performed using Tukey's HSD tests. Analyses of the data also included statistical correlations and statistical differences between related variables.

Spearman's correlation tests were performed on various data sets, in order to examine the relationships between the corresponding variables. These tests assessed the linear relationships between variables/parameters, and they were performed using Spearman's rank-order linear relationships, by examining the coefficients of correlation $\mathrm{R}$ and the coefficients of determination $\mathrm{R}^{2}$, which range between -1.0 and +1.0 . The stronger the relationship between the variables/parameters, the higher the coefficient of correlation $\mathrm{R}$ and the coefficient of determination $\mathrm{R}^{2}$. Coefficients of correlation $\mathrm{R}$ of -1.0 and +1.0 represent perfect correlation between the variables/parameters under examination. Coefficients of correlation of $\leq(-0.5)$ and $(+0.5)$ were regarded as indicating variables/parameters having a strong correlation and relationship. Variables/parameters having coefficients of correlation $\mathrm{R} \geq(-0.5)$ and (+0.5), were regarded as having poor correlation and relationship.

\section{RESULTS AND DISCUSSIONS}

\section{Variation of physical-chemical characteristics}

Table 1 summarizes the values of the observed Lubigi wetland water inlet and outlet nitrogen, faecal coliforms and related physical-chemical parameters.

Table 1: Variation of physical parameters in Lubigi Wetland

\begin{tabular}{|l|c|c|c|c|}
\hline \multirow{2}{*}{ Parameter } & \multicolumn{2}{|c|}{ Inlet Values } & \multicolumn{2}{c|}{ Outlet Values } \\
\cline { 2 - 5 } & Min - Max & Mean \pm SD & Min - Max & Mean \pm SD \\
\hline $\mathrm{pH}$ & $6.60-8.10$ & $7.22 \pm 0.34$ & $6.80-8.00$ & $7.24 \pm 0.29$ \\
\hline Temperature $\left({ }^{\circ} \mathrm{C}\right)$ & $19.7-22.4$ & $21.2 \pm 0.71$ & $20.5-24.8$ & $22.6 \pm 1.06$ \\
\hline Dissolved Oxygen $(\mathrm{mg} / \mathrm{l})$ & $0.06-2.43$ & $0.30 \pm 0.37$ & $0.07-0.64$ & $0.23 \pm 0.10$ \\
\hline
\end{tabular}

Min-minimum and Max-maximum

\section{The pH}

Table 1 shows that in the wetland main inlet zone, the $\mathrm{pH}$ of the water ranged from 6.7 to 8.1 with a mean value of $7.22 \pm 0.34$, while in the outlet zone, the $\mathrm{pH}$ varied from 6.8 to 8.0 with a mean value of $7.24 \pm 0.29$. Statistical analyses showed that at the $95 \%$ confidence interval $(\alpha=0.05)$, there was no significant difference between the wetland inlet and outlet $\mathrm{pH}$ values $(\mathrm{p}=0.143)$ although there is a positive linear correlation $\left(\mathrm{R}^{2}=0.391\right)$, between the wetland outlet and inlet $\mathrm{pH}$ values. The range of the observed outlet $\mathrm{pH}$ values suggests that microbial activities in the wetland are favored, since 
these values fall within the optimum functioning $\mathrm{pH}$ range of microbes (Kadlec, 2009).

In particular, mineralization having the optimum $\mathrm{pH}$ range of 6.5 to 8.5 (Patrick and Wyatt, 1964), and denitrification by Pseudomonas bacteria having the optimum $\mathrm{pH}$ range of 7.0 to 8.0 (Delwiche and Bryan, 1978; Muller et al., 1999) are favored to occur at appreciable rates. However, nitrification by Nitrosomonas bacteria having the optimum $\mathrm{pH}$ range of 8.5 to 8.8 , and by Nitrobacter bacteria having the optimum $\mathrm{pH}$ range of 8.3 to 9.3 (Halling-Sorensen and Jorgensen, 1993), appears to be less favored to occur at high rates. The range of the observed outlet $\mathrm{pH}$ values, also favors ammonia-nitrogen to exist predominantly in the ionizedammonium $\left(\mathrm{NH}_{4}{ }^{+}\right)$form, rather than in the volatilized un-ionized-ammonia gas $\left(\mathrm{NH}_{3}(\mathrm{~g})\right)$ form, which starts to become predominant at $\mathrm{pH}$ values above 9.0 (Konig et al., 1987).

\section{Dissolved oxygen}

From Table 1, the dissolved oxygen concentrations in the main inlet zone, ranged from 0.06 to $2.43 \mathrm{mg} / \mathrm{l}$, with a mean value of $0.32 \mathrm{mg} / \mathrm{l}$, whereas in the outlet zone, the dissolved oxygen concentrations ranged from 0.07 to 0.64 $\mathrm{mg} / \mathrm{l}$, with a mean value of $0.24 \mathrm{mg} / \mathrm{l}$ at the 95\% confidence interval $(\alpha=0.05)$. Further statistical analyses showed that there is a statistically significant difference between the inlet and outlet dissolved oxygen concentrations $(\mathrm{p}=0.014)$ and a very weak and positive linear correlation $(\mathrm{R}=0.23)$, between the wetland outlet and inlet $\mathrm{pH}$ values. The observed dissolved oxygen (DO) concentration values, suggest that the Lubigi wetland has very low levels of aeration and oxygenation, and it is therefore by and large anoxic. The dissolved oxygen concentrations decreased by $26.7 \%$ in the wetland, suggesting that the water is significantly de-oxygenated by the high Biochemical Oxygen Demand (BOD) related to the biogeochemical activities taking place in the wetland, including nitrification and the biodegradation by microorganisms of organic matter in the wastewater, and the decaying plant litter/detritus.

Algal photosynthesis, which contributes to the oxygenation of wetlands, does not appear to be playing a major role in the Lubigi wetland although wetland received 469 to $578 \mathrm{cal} / \mathrm{m}^{2} / \mathrm{d}$ of solar intensity $\left(\right.$ Mean $\left.=525 \mathrm{cal} / \mathrm{m}^{2} / \mathrm{d}\right)$. It is worth to report that the average plant density in Lubigi wetland is 10.2 plants $/ \mathrm{m}^{2}$ (Kayima and Mayo, 2018), which is about three times higher than 3.2 plants $/ \mathrm{m}^{2}$ in Mara River Basin wetlands in Tanzania (Muraza et al., 2014). The thick canopy of the dense emergent macrophytes prevalent in the Lubigi wetland has a sheltering and shadowing effect, obstructing sunlight from reaching the wetland water column and thus curtailing the growth of algae, photosynthesis and oxygen production. In addition, dense emergent macrophytes tend to reduce wind velocities and the related physical re-aeration and oxygenation actions on the wetland waters. Hence in general, nitrification by Nitrosomonas bacteria having the optimum dissolved oxygen concentration range of 2.0 to $7.5 \mathrm{mg} / \mathrm{l}$, and Nitrobacter bacteria having the optimum dissolved oxygen concentration of 4.0 to $7.5 \mathrm{mg} / \mathrm{l}$ (Knowles et al., 1965; Senzia, 2003) is not favored to occur at high rates. However, denitrification by Pseudomonas bacteria having the optimum dissolved oxygen concentration range of less than $0.5 \mathrm{mg} / \mathrm{l}$ (Halling-Sorensen and Jorgensen, 1993) is favored to occur at appreciable rates.

\section{Water temperatures}

From Table 1, water temperatures in the main inlet zone range from $19.7^{\circ} \mathrm{C}$ to $22.4^{\circ} \mathrm{C}$, with a mean value of $21.2 \pm 0.71$ ${ }^{\circ} \mathrm{C}$, whereas in the outlet zone, water 
temperatures range from $20.5^{\circ} \mathrm{C}$ to $24.8^{\circ} \mathrm{C}$, with a mean value of $22.6 \pm 1.06{ }^{\circ} \mathrm{C}$. Figure 2 shows that there is a positive, but low linear correlation $(\mathrm{R}=0.49)$, between outlet and inlet water temperatures, which suggests that wetland temperature is relatively independent of inlet temperature. On average, wetland temperature increased by $1.4^{\circ} \mathrm{C}$, although statistical analysis at the $95 \%$ confidence interval $(\alpha=0.05)$, suggests that there is no significant difference between the inlet and outlet temperatures $(\mathrm{p}=0.161)$. The observed water temperature values suggest that mineralization having a limiting minimum temperature of about $11^{\circ} \mathrm{C}$ to $14^{\circ} \mathrm{C}$ (U.S. Environmental Protection Agency, 2000) is favored to occur at appreciable rates. However, nitrification by Nitrosomonas bacteria having the optimum temperature range of $28^{\circ} \mathrm{C}$ to $36^{\circ} \mathrm{C}$, and Nitrobacter bacteria having the optimum temperature range of $28^{\circ} \mathrm{C}$ to $42^{\circ} \mathrm{C}$ (Painter, 1970), is not favored to occur at a high rate. On the other hand, denitrification by Pseudomonas bacteria having the optimum temperature range of $3^{\circ} \mathrm{C}$ to $35^{\circ} \mathrm{C}$ can proceed at appreciable rates.

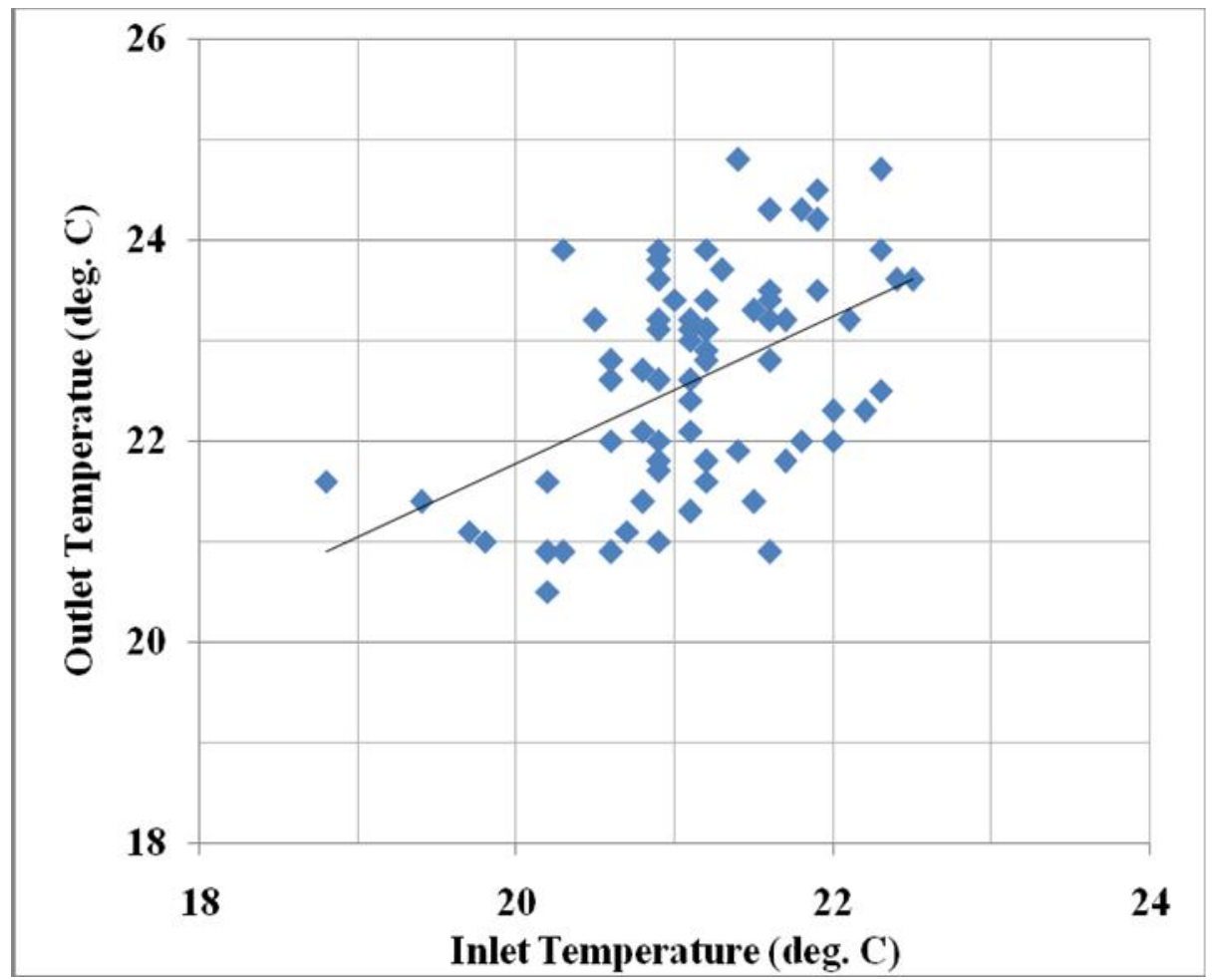

Figure 2: Correlation between wetland outlet and inlet water temperatures

\section{Ammonia-nitrogen in the wetland}

The concentration of ammonia-nitrogen in the inlet ranged from $1.23 \mathrm{mg} / \mathrm{l}$ to 73.6 $\mathrm{mg} / \mathrm{l}$, with a mean value of $29.1 \pm 18.3$ $\mathrm{mg} / \mathrm{l}$. However, the concentration of ammonia-nitrogen in the wetland outlet varied from 0.71 to $61.0 \mathrm{mg} / \mathrm{l}$ with a mean value of $21.9 \pm 14.0 \mathrm{mg} / \mathrm{l}$. Further statistical analyses showed that there is a statistically significant difference between the wetland inlet and outlet ammonia- nitrogen concentrations $(\mathrm{p}=0.037)$. These high ammonia-nitrogen concentration values can be attributed to the presence of wastewater discharged into the Lubigi wetland. In particular, the process of mineralization of organic-nitrogen to ammonia-nitrogen appears to be proceeding at significant rates due to the $\mathrm{pH}$ and temperature conditions which favor this process, as already discussed. There is also the indication that the originally settled organic-nitrogen is being 
regenerated back into the water column as ammonia-nitrogen, especially during the rainy and flash floods periods when conditions of hydraulic turbulence are set in motion.

It was observed that the average ammonianitrogen removal efficiency was $24.7 \%$. This relatively low overall removal efficiency appears to be due to low rates of nitrification as a result of unfavorable dissolved oxygen levels. It is possible that due to the high plants densities, plant uptake may be the major process governing ammonia-nitrogen removal in the wetland. Figure 3 shows that there is a very strong and positive linear correlation/relationship ( $\mathrm{R}=0.88)$, between the wetland outlet and inlet ammonianitrogen. The observed mean value of outlet ammonia-nitrogen of $21.9 \mathrm{mg} / \mathrm{l}$ is more than double the recommended Uganda National Effluent Discharge Standard of $10.0 \mathrm{mg} / \mathrm{l}$ (Uganda National Environmental Management Authority (NEMA), 2016). This implies that the overall ammonia-nitrogen $\left(\mathrm{NH}_{3}-\mathrm{N}\right)$ removal capacity of the Lubigi wetland main study area, does not meet the recommended standards, before disposing effluents into the environment.

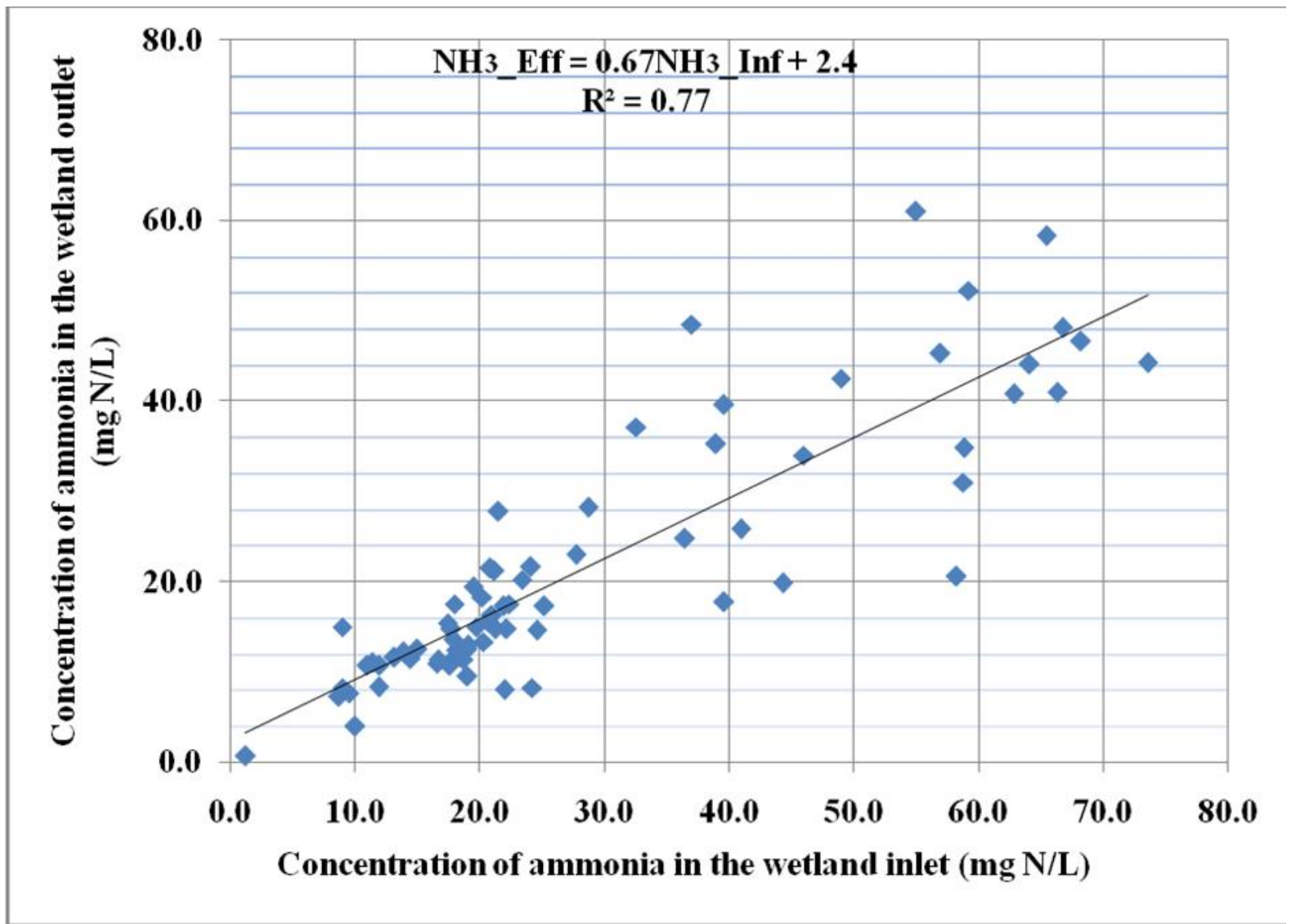

Figure 3: Correlation between wetland outlet $\mathrm{NH}_{3}-\mathrm{N}$ and inlet $\mathrm{NH}_{3}-\mathrm{N}$

\section{Nitrate-nitrogen in the Lubigi Wetland}

Figure 4 shows that there is a very strong linear correlation/relationship $(\mathrm{R}=0.74)$ between the wetland outlet and inlet nitrate-nitrogen. The concentration of nitrate-nitrogen $\left(\mathrm{NO}_{3}-\mathrm{N}\right)$ in the wetland inlet ranged from 0.01 to $1.64 \mathrm{mg} / \mathrm{l}$, with a mean value of $0.15 \pm 0.20 \mathrm{mg} / \mathrm{l}$, and in the outlet it varied from 0.01 to $0.81 \mathrm{mg} / \mathrm{l}$, with a mean value of $0.09 \pm 0.14 \mathrm{mg} / \mathrm{l}$. Statistical analysis revealed that there is a significant difference between the inlet and outlet ammonia-nitrogen concentrations ( $p$ 
$=0.024)$. It was noted that the mean outlet nitrate-nitrogen concentration of $0.09 \mathrm{mg} / \mathrm{l}$ was well below the recommended Uganda National Effluent Discharge Standard of $10.0 \mathrm{mg} / \mathrm{l}$ (Uganda NEMA, 2016), implying that the overall nitrate-nitrogen removal capacity of the Lubigi wetland main study area, meets the recommended standards, before disposing effluents into the environment.

The noticeably low nitrate-nitrogen concentration values appear to confirm the earlier observations and discussions, that the process of nitrification to form nitratenitrogen is constrained by the dissolved oxygen level in the wetland. Furthermore, this may be confirming the earlier observations that denitrification may be proceeding and removing nitrate-nitrogen at considerable rates due to favorable $\mathrm{pH}$, dissolved oxygen and temperature conditions in the wetland. There is also indication that due to the high plants densities, the process of plant uptake is also playing a significant role in the removal of nitrate-nitrogen.

The average nitrate-nitrogen removal efficiency of $40.0 \%$ provides further evidence that denitrification may be proceeding and removing nitrate-nitrogen, at considerable rates. This denitrification would be well supported, especially due to the presence of the abundant labile organic carbon sources in the wastewater and the decaying plant detritus, acting as electron donors in favor of this process. In addition, it is possible that plant uptake is also playing a significant role in the removal of nitrate-nitrogen.

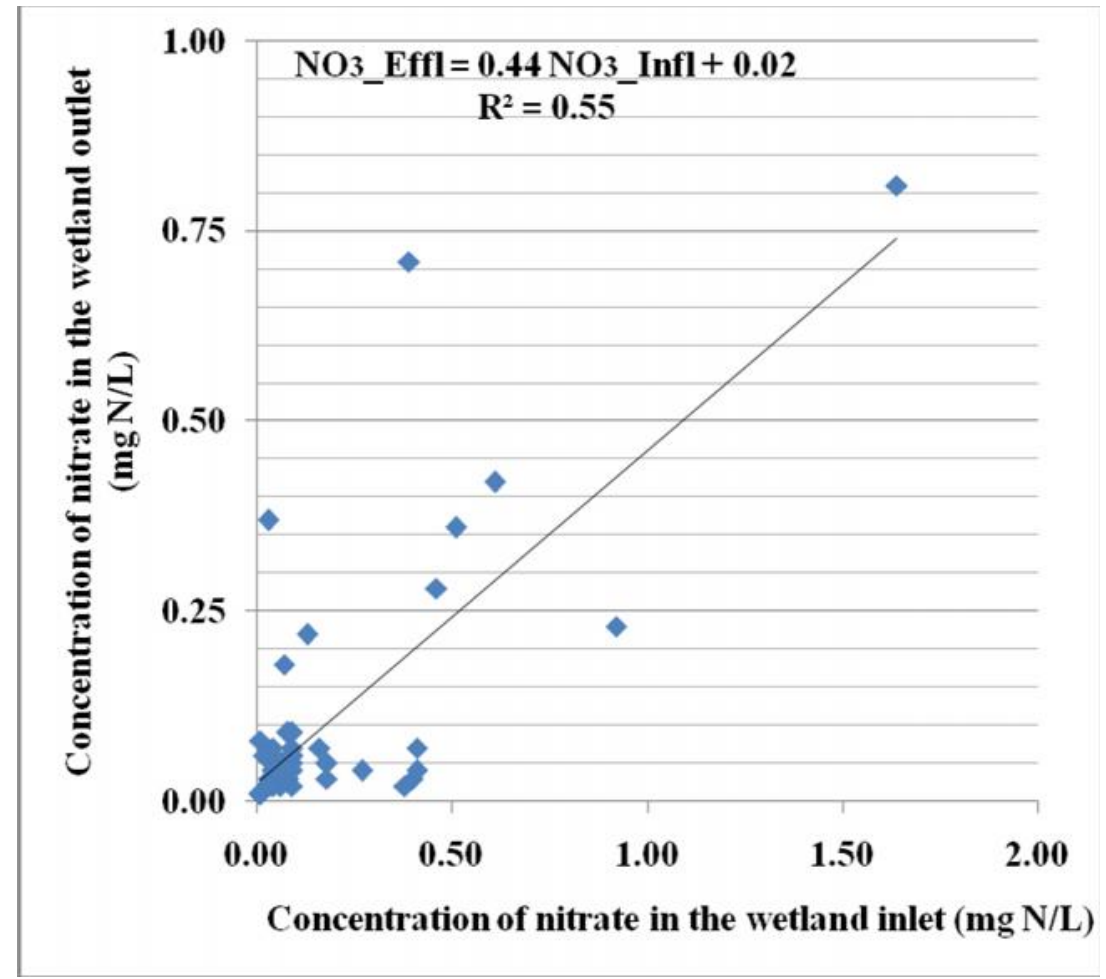

Figure 4: Correlation between wetland outlet $\mathrm{NO}_{3}-\mathrm{N}$ and inlet $\mathrm{NO}_{3}$

\section{Organic-nitrogen in the Lubigi wetland}

Measurements of organic-nitrogen revealed that its concentration in the wetland inlet ranged from 4.4 to 134.2 $\mathrm{mg} / \mathrm{l}$, with a mean value of $53.6 \pm 37.3$ $\mathrm{mg} / \mathrm{l}$. In the wetland outlet zone, the concentration of organic-nitrogen varied from $1.6 \mathrm{mg} / \mathrm{l}$ to $110 \mathrm{mg} / \mathrm{l}$, with a mean 
value of $40.1 \pm 33.8 \mathrm{mg} / \mathrm{l}$. It was further observed that there is a statistically significant difference between the wetland inlet and outlet ammonia-nitrogen concentrations $(p=0.013)$. Figure 5 also shows that there is a strong linear correlation/relationship $(\mathrm{R}=0.78)$ between the wetland outlet and inlet organicnitrogen. The observed mean value of outlet organic-nitrogen of $53.6 \mathrm{mg} / \mathrm{l}$, is more than double the recommended Uganda National Effluent Discharge Standard of $20.0 \mathrm{mg} / \mathrm{l}$ (Uganda NEMA, 2016), implying that the overall organicnitrogen removal capacity of the Lubigi wetland main study area, does not meet the recommended standards, before disposing effluents into the environment.
The organic-nitrogen concentration in the wetland inlet was noticeably high and can be attributed to the presence of wastewater discharged into the Lubigi wetland. Furthermore, there is suggestion that due to the high plant densities, the leaching of the abundant decaying dead plant detritus makes a significant contribution to the recycling of organic-nitrogen (Org-N) back into the water column. The average organic-nitrogen removal efficiency was $25.1 \%$, which might have been attributed to the process of mineralization of the Org$\mathrm{N}$ to $\mathrm{NH}_{3}-\mathrm{N}$. In addition, the sedimentation of organic-nitrogen into the wetland benthic layers, may also be contributing significantly to the overall removal of organic-nitrogen from the water column.

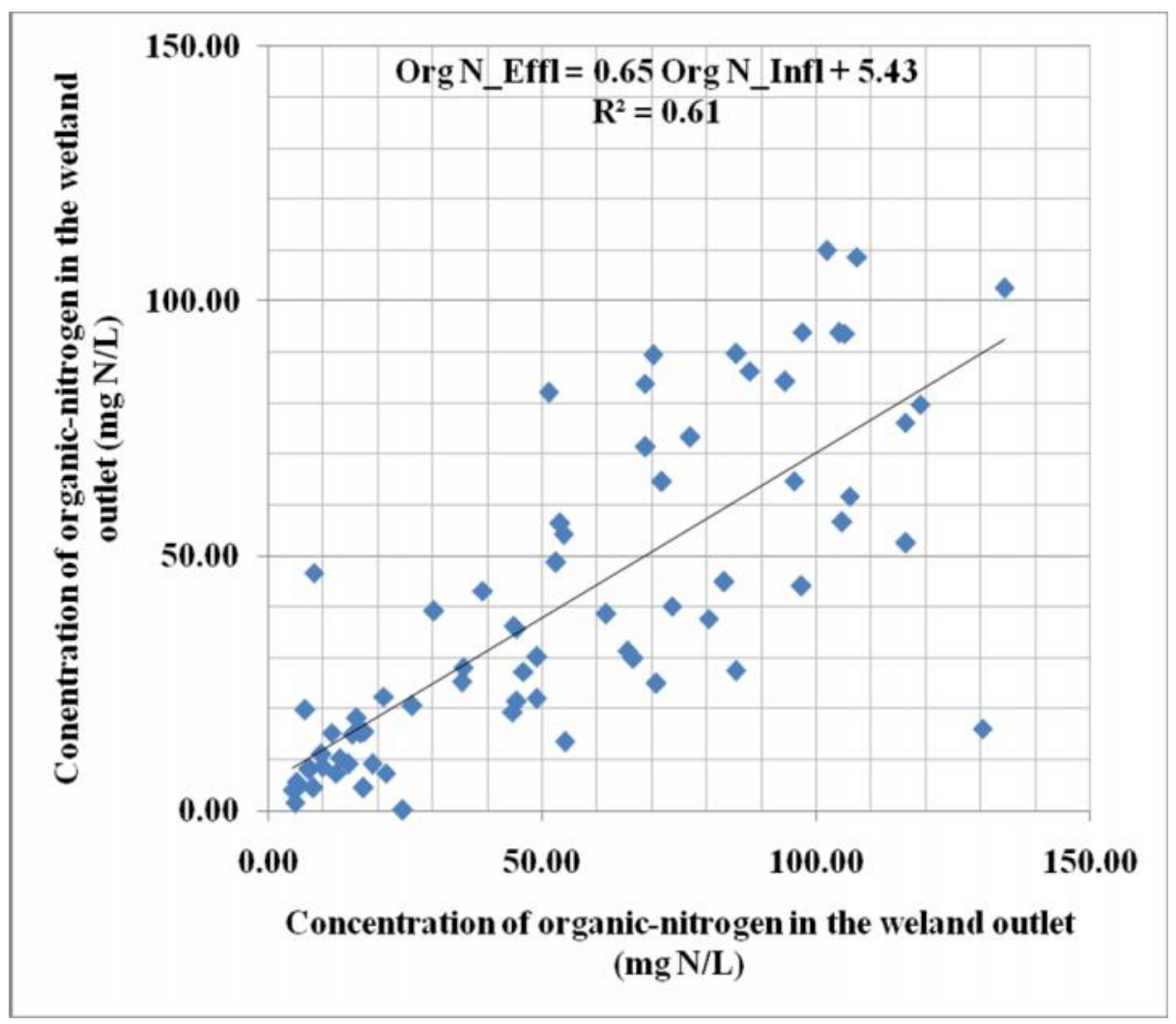

Figure 5: Correlation between wetland outlet Org-N and inlet Org-N

\section{Total nitrogen in the Lubigi wetland}

In accordance with the data collected, the concentration of total-nitrogen varied from 16 to $173 \mathrm{mg} / \mathrm{l}$, with a mean value of $83.1 \pm 44.7 \mathrm{mg} / \mathrm{l}$ in the wetland inlet zone, and from 10 to $167 \mathrm{mg} / \mathrm{l}$, with a mean value of $62.4 \pm 36.8 \mathrm{mg} / \mathrm{l}$ in the outlet zone. Further statistical analyses show that there is a statistically significant difference between the wetland inlet and outlet ammonia-nitrogen concentrations $(\mathrm{p}=$ 
0.035). The average total-nitrogen removal efficiency was $24.9 \%$, which is an appreciable amount considering that the mean hydraulic residence time is only about 2.0 days (Kayima et al., 2018b). This removal is largely through net-loss by sedimentation, plants uptake and denitrification.

Figure 6 also shows that there is a strong linear correlation $(R=0.81)$ between the wetland outlet and inlet total-nitrogen. The observed mean value of outlet totalnitrogen of $83.1 \mathrm{mg} / \mathrm{l}$, is more than double the recommended Uganda National Effluent Discharge Standard of $20.0 \mathrm{mg} / \mathrm{l}$ (Uganda NEMA, 2016), implying that the overall total-nitrogen removal capacity of the Lubigi wetland main study area, does not meet the recommended standards, before disposing effluents into the environment.

This section of the wetland has removed $20.7 \mathrm{mg} / \mathrm{l}$ of nitrogen. With the average flow rate of $221,357 \mathrm{~m}^{3} / \mathrm{d}$ (Kayima et al., 2018), the wetland has a capacity to remove $4,582 \mathrm{kgN} / \mathrm{d}$, which is equivalent to 1,672 tons/year. Although substantial amount of nitrogen is removed in this section of the wetland, about 5,040 tons/day of nitrogen is discharged at the outlet end of the wetland, which suggests that significant quantity of nitrogen received from the upstream is discharged at the downstream end without removal. This could lead to pollution of water bodies downstream of Lubigi wetland.

\section{Nitrogen content in wetland sediments}

Sediment samples indicate that at transect T3 the concentration of nitrogen was $0.60 \pm 0.22 \mathrm{gN} / \mathrm{kg}$ sediments. However, at transects $\mathrm{T} 1$ and $\mathrm{T} 2$, the samples concentration of nitrogen was $0.16 \pm 0.12$ and $\quad 0.14 \pm 0.12 \mathrm{gN} / \mathrm{kg}$ sediments, respectively. The average nitrogen content in the sediments was $0.30 \pm 0.15 \mathrm{gN} / \mathrm{kg}$ sediments, which translates to $157.5 \mathrm{gN.m}{ }^{-}$ 2 of wetland. It is evident that there is a general trend of more nitrogen accumulating in the sediments as the wetland water flows from wetland inlet to the outlet. This can be attributed to the simultaneous trend of increase in plants densities from wetland upstream zones towards the downstream ends. Table 2 summarizes the results of the Lubigi wetland plants biomass and nitrogen contents. The corresponding increase in the below-ground roots and rhizomes structures of these plants is responsible for the trapping of increasing sediments quantities, which in turn determine the increasing quantities of nitrogen trapped in the sediments.

\section{Nitrogen content in wetland sediments}

Sediment samples indicate that at transect T3 the concentration of nitrogen was $0.60 \pm 0.22 \mathrm{gN} / \mathrm{kg}$ sediments. However, at transects $\mathrm{T} 1$ and $\mathrm{T} 2$, the samples concentration of nitrogen was $0.16 \pm 0.12$ and $\quad 0.14 \pm 0.12 \mathrm{gN} / \mathrm{kg}$ sediments, respectively. The average nitrogen content in the sediments was $0.30 \pm 0.15 \mathrm{gN} / \mathrm{kg}$ sediments, which translates to $157.5 \mathrm{gN} . \mathrm{m}^{-}$ 2 of wetland. It is evident that there is a general trend of more nitrogen accumulating in the sediments as the wetland water flows from wetland inlet to the outlet. This can be attributed to the simultaneous trend of increase in plants densities from wetland upstream zones towards the downstream ends. Table 2 summarizes the results of the Lubigi wetland plants biomass and nitrogen contents. The corresponding increase in the below-ground roots and rhizomes structures of these plants is responsible for the trapping of increasing sediments quantities, which in turn determine the increasing quantities of nitrogen trapped in the sediments. 


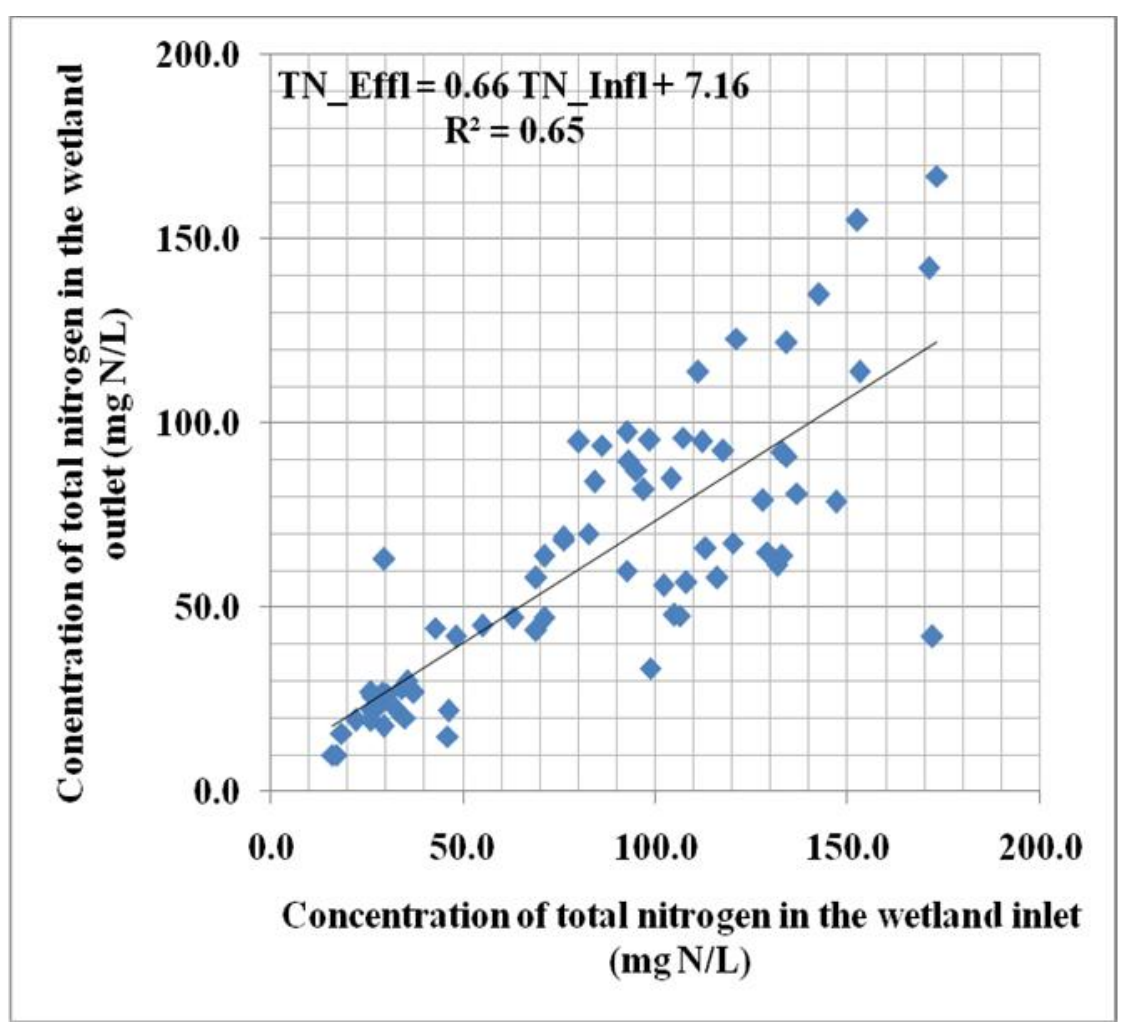

Figure 6: Correlation between wetland outlet $\mathrm{TN}$ and inlet $\mathrm{TN}$

Table 2: Lubigi Wetland Plants Biomass and Nitrogen Contents

\begin{tabular}{|l|l|c|c|c|c|c|c|}
\hline Item & & $\begin{array}{c}\text { Cyperus } \\
\text { Papyrus }\end{array}$ & $\begin{array}{c}\text { Echinochloa } \\
\text { pyramidalis }\end{array}$ & $\begin{array}{c}\text { Typha } \\
\text { capensis }\end{array}$ & $\begin{array}{c}\text { Rottboellia } \\
\text { cochinchinensis }\end{array}$ & $\begin{array}{c}\text { Oldenlandia } \\
\text { lancifolia }\end{array}$ & Average \pm SD \\
\hline \multirow{2}{*}{$\begin{array}{l}\text { Biomass } \\
\left(\mathrm{kgDW} / \mathrm{m}^{2}\right)\end{array}$} & $\mathrm{AG}$ & $0.55 \pm 0.48$ & $0.14 \pm 0.10$ & $0.21 \pm 0.16$ & $0.023 \pm 0.015$ & $0.28 \pm 0.28$ & $0.24 \pm 0.09$ \\
\cline { 2 - 9 } & $\mathrm{BG}$ & $0.46 \pm 0.23$ & $0.03 \pm 0.02$ & $0.05 \pm 0.03$ & $0.005 \pm 0.003$ & $0.09 \pm 0.09$ & $0.13 \pm 0.08$ \\
\cline { 2 - 8 } & Total & $1.01 \pm 0.05$ & $0.17 \pm 0.06$ & $0.26 \pm 0.08$ & $0.028 \pm 0.009$ & $0.37 \pm 0.01$ & $0.37 \pm 0.17$ \\
\hline \multirow{2}{*}{$\begin{array}{l}\text { Nitrogen } \\
\text { Contents } \\
(\% \mathrm{DW})\end{array}$} & $\mathrm{AG}$ & $0.22 \pm 0.14$ & $0.56 \pm 0.31$ & $0.17 \pm 0.10$ & $0.038 \pm 0.038$ & $0.03 \pm 0.03$ & $0.20 \pm 0.09$ \\
\cline { 2 - 8 } & $\mathrm{BG}$ & $0.19 \pm 0.11$ & $0.1 \pm 0.09$ & $0.04 \pm 0.02$ & $0.004 \pm 0.004$ & $0.01 \pm 0.01$ & $0.07 \pm 0.03$ \\
\hline \multirow{2}{*}{$\begin{array}{l}\text { Nitrogen } \\
\text { Contents } \\
\left(\mathrm{gm}^{-2}\right)\end{array}$} & $\mathrm{AG}$ & $0.41 \pm 0.12$ & $0.66 \pm 0.23$ & $0.21 \pm 0.07$ & $0.042 \pm 0.017$ & $0.04 \pm 0.01$ & $0.27 \pm 0.12$ \\
\cline { 2 - 8 } & $\mathrm{BG}$ & 87.4 & 3.0 & 2.0 & 0.9 & 8.4 & $48.89 \pm 22.57$ \\
\cline { 2 - 8 } & Total & 208.4 & 81.4 & 37.7 & 0.9 & 9.3 & $67.54 \pm 37.91$ \\
\hline
\end{tabular}

$\mathrm{BG}=$ Below-Ground plant organs; $\mathrm{AG}=$ Above-Ground plant organs; DW = Dry Weight; SD $=$ Standard deviation

\section{Faecal Coliforms in the Lubigi Wetland}

The concentration of faecal coliform in the wetland inlet ranged from 60 to 4,800,000 $\mathrm{cfu} / 100 \mathrm{ml}$ with a mean value of $653,509 \pm 2,182 \mathrm{cfu} / 100 \mathrm{ml}$. In the wetland outlet zone, faecal coliform counts varied from 20 to $740,000 \mathrm{cfu} / 100 \mathrm{ml}$, with a mean value of $218,676 \pm 157 \mathrm{cfu} / 100 \mathrm{ml}$. Therefore, this gives an average faecal coliform removal efficiency of $66.5 \%$.
However, the quality of effluent is far above the recommended Uganda National Effluent Discharge Standard of 5,000 CFU/100ml (Uganda National Environmental Management Authority (NEMA), 2016). This implies that the wetland outlet faecal coliform (FC) concentrations of the Lubigi wetland main study area, do not meet the recommended faecal coliform (FC) standards. However, when the logarithm values of the wetland inlet and outlet faecal coliform was 
plotted, a strong correlation was observed $(\mathrm{R}=0.95)$. The high faecal coliform (FC) concentration in the inlet can be attributed to the wastewater discharged into the Lubigi wetland from the open channel drains and from Lubigi sewage treatment plant. Although treatment of wastewater is done in Lubigi sewage treatment plant the effluent quality is still poor. In several occasions raw sewage is directly by-passed into the wetland when the plant is overloaded or when it is undergoing maintenance and repairs.

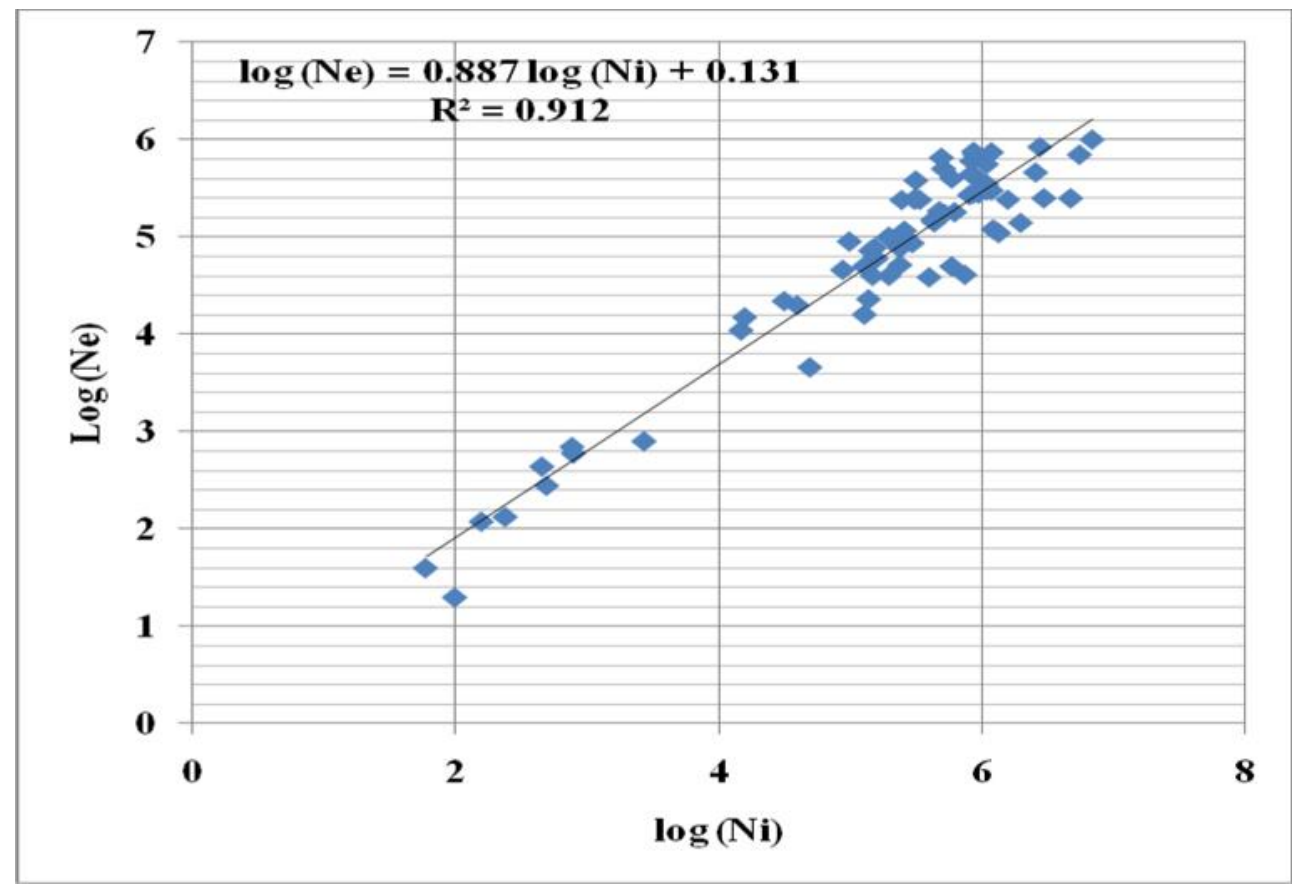

Figure 7: Correlation between the wetland outlet FC and inlet FC

In a study carried out by Kansiime and Nalubega (1999) in the Nakivubo swamp in Uganda, a relatively higher faecal coliform removal efficiency of $90.9 \%$ was reported. This wetland receives wastewater from the Nakivubo storm water channel and effluents from the Bugolobi sewage treatment plant was reported to contain mean faecal coliform (FC) concentrations of $110,000 \pm 26,000 \mathrm{cfu} / 100 \mathrm{ml}$ in the inlet and $10,000 \pm 2,400 \mathrm{cfu} / 100 \mathrm{ml}$ in the wetland outlet zones. In another study by Mayo and Kalibbala (2007) in constructed water hyacinth ponds in the University of Dar es Salaam in Tanzania, which received sewage effluents from the waste stabilization ponds, faecal coliform (FC) concentrations was reduced from $136,000 \pm 16,600 \quad \mathrm{cfu} / 100 \mathrm{ml}$ in the wetland inlet zone, to a mean value of $83,900 \pm 10,200 \mathrm{cfu} / 100 \mathrm{ml}$ in the outlet zone. This reduction is equivalent to a mean faecal coliform removal efficiency of $38.3 \%$. For comparison, Kalunde (2007) reported removal efficiency of faecal coliform of $96.0 \%$ in a horizontal subsurface flow constructed wetland at the University of Dar es Salaam wastewater treatment facility. It is evident that faecal coliform removal efficiency varies from one system to another depending on the type of wetland and variations of physical, environmental and forcing functions affecting each system. 


\section{CONCLUSIONS}

From the foregoing results and discussion, it is evident that the Lubigi wetland receives varying concentration of total nitrogen varying from 16 to $173 \mathrm{mg} / \mathrm{l}$, largely in form of organic-nitrogen $(64.7 \%)$ and ammonia-nitrogen $(35.2 \%)$. The wetland removed about $24.9 \%$ of this nitrogen largely through net-loss by plants uptake, sedimentation and denitrification. The Lubigi wetland main study area has total-nitrogen (TN) mean values of approximately $83.1 \mathrm{mg} / \mathrm{l}$ and $62.4 \mathrm{mg} / \mathrm{l}$, in the wetland inlet and outlet zones, respectively. The mean effluent discharge is approximately $221,357 \mathrm{~m}^{3} / \mathrm{d}$, and the total area of the whole wetland is approximately $2.98 \mathrm{~km}^{2}$. Hence, the whole wetland removes approximately 1,672 tons of nitrogen per year, which is equivalent to about $5,610 \mathrm{~kg} / \mathrm{ha} /$ year. The analyses of the plants nitrogen contents, also indicate that significant amounts of nitrogen amounting to about $675.4 \mathrm{~kg} / \mathrm{ha}$, which is equivalent to approximately 202 tons, are contained in the plants biomass, and are thus considered to be removed by the wetland. In addition, the Lubigi wetland main study area also receives faecal coliform concentrations with inlet mean value of $653,509 \mathrm{CFU} / 100 \mathrm{ml}$ and its outlet mean value is $218,676 \mathrm{CFU} / 100 \mathrm{ml}$. These values give a faecal coliform (FC) overall removal efficiency of approximately $66.5 \%$. These are substantial amounts of nitrogen and faecal coliforms, which have been prevented from entering the Mayanja River and Lake Kyoga. Evidently, the Lubigi wetland has considerable capacity to buffer and protect Lake Kyoga by reducing nitrogen and faecal pollution entering the lake. The nutrients retained in the wetland has sustained habitat for diverse and endemic flora and fauna, which is important to the ecosystem. It is further recommended to develop tools for prediction and management of nutrient dynamics in the wetland.

\section{REFERENCES}

American Public Health Association, American Water Works Association, Water Pollution Control Federation, Water Environment Federation (2012). Standard Methods for Examination of Water and Wastewater, $22^{\text {th }}$ Edition, Washington, DC, USA.

Baker D.M., Rodriguez-Martinez R.E. and Fogel M.L. (2013). Tourism's nitrogen footprint on a Mesoamerican coral reef. Coral Reefs, 32: 691-699.

Bavor H.J. and Waters M.T. (2008). Buffering Performance in a Papyrus Dominated Wetland System of the Kenyan Portion of the Lake Victoria Basin. In: Vymazal J. (ed.); Wastewater Treatment, Plant Dynamics and Management in Constructed and Natural Wetlands. Proceedings of the $6^{\text {th }}$ Workshop on Nutrient Cycling in Natural and Constructed Wetlands, Trebon, Czech Republic, Springer, Dordrecht, 33-38.

Brender J.D., Weyer P.J., Romitti P.A., Mohanty B.P., Shinde M.U., Vuong A.M., Sharkey J.R., Dwevedi D., Horel S.A., Kantamneni J., Huber Jr. J.C., Zheng Q., Werler M.M., Kelley K.E., Griesenbeck J.S., Zhan F.B., Langlois P.H., Suarez L. and Canfield M.A. (2013). Prenatal nitrate intake from drinking water and selected birth defects in offspring of participants in the National Birth Defects Prevention Study. Environ Health Perspect, 121: 1083 - 1089.

Bricker S.B., Longstaff B., Dennison W., Jones A., Boicourt K., Wicks C. and Woerner J. (2008). Effects of nutrient enrichment in the nation's estuaries: a decade of change. Harmful Algae, 8: 21-32.

Delwiche C.C. and Bryan B.A. (1978). Denitrification. Annual Review of Microbiology, 30: 241-262. 
Gumm E. (2011). The Use and Misuse of Wetlands in Kampala. SIT Graduate Institute/SIT Digital Collections.

Halling-Sorensen B. and Jorgensen S.E. (1993). The Removal of Nitrogen Compounds from Wastewater. Studies in Environmental Science, 54, Elsevier, Amsterdam.

Henry L. and Semili P. (2005). Levels of heavy metal pollution in water and sediments in Simiyu wetland of Lake Victoria basin (Tanzania). In: Odada O., Olago D.O., Ochola W., Ntiba M., Wandiga S., Gichuki N., Oyieke H. (Eds.). Proceedings of the $11^{\text {th }}$ World Lakes Conference, Nairobi, Kenya, 549-553.

Kadlec R.H. (2009). Wastewater Treatment at Houghton Lake, Michigan: Hydrology and Water Quality. Journal of Ecological Engineering, 35: 1287-1311.

Kalibbala M., Mayo A.W., Asaeda T. and Shilla D.A. (2008). Modelling faecal streptococci mortality in constructed wetlands with Eichhornia crassipes. Wetland Ecol. Management, 16: 499510.

Kalunde K. (2007). Modelling of Faecal Coliform Removal Using the STELLA Software. A Case of Horizontal Sub-surface Flow Constructed Wetland in Tanzania. MSc. Dissertation, Department of Civil Engineering, University of Zimbabwe, Zimbabwe.

Kansiime F. and Nalubega M. (1999). Wastewater Treatment by a Natural Wetland: The Nakivubo Swamp, Uganda. A. A. Balkema, Rotterdam, The Netherlands.

Karr C. (2012). Children's Environmental Health in Agricultural Settings. Journal of Agromedicine, 17(2): 127139.

Kayima J.K., Mayo A.W. and Norbert J. (2018a). Ecological characteristics and morphological features of the Lubigi Wetland in Uganda'. Environment and
Ecology Research, 6(4): 218-228. DOI: 10.13189/eer.2018.060402.

Kayima J.K., Mayo A.W. and Norbert J. (2018b). Hydrology and hydraulics of the Lubigi wetland in Uganda, Tanzania Journal of Engineering and Technology, 37(1): 1-18.

Kayima J.K. and Mayo A.W. (2018). Characteristics of macrophytes in the Lubigi Wetland in Uganda'. International Journal of Biodiversity and Conservation, 10(10): 394-406, DOI: 10.5897/IJBC2018.1206.

Kinney E.L. and Valiela I. (2013). Changes in delta $\mathrm{N}-15$ in salt marsh sediments in a long-term fertilization study. Marine Ecology Progress Series, 477: 41-52.

Knowles G., Downing A.L. and Barrett M.J. (1965). Determination of Kinetic Constants for Nitrifying Bacteria in Mixed Culture, With the Aid of Electronic Computer. Journal of Microbiology, 38: 263-278.

Konig A., Pearson H.W. and Silva S.A. (1987). Ammonia Toxicity to Algae Growth in Waste Stabilization Ponds. J. Water Sciences and Technology, 19(12): 155-122.

Li M., Yu N., Qin J.G., Li E., Du Z., Chen L. (2014). Effects of ammonia stress, dietary linseed oil and Edwardsiella ictaluri challenge on juvenile darkbarbel catfish Pelteobagrus vachelli. Fish and Shellfish Immunology, 38(1): 158-165.

Marwa A. (2013). Treatment of Acid Mine Drainage From North Mara Mine Using Constructed Wetlands. MSc (Eng) Thesis, Department of Chemical and Mining Engineering, University of Dar es Salaam, Tanzania.

Masawe E.J., Kimwaga R. and Mwanuzi F. (2018). Modelling Transport of Heavy Metals in Geita Wetland along Mamubi River. Tanz. J. Engrg. Technol., 37(1): 72-88.

Mayo A.W. and Kalibbala M. (2007). Modelling Fecal Coliform Mortality in Water Hyacinths Ponds. Physics and 
Chemistry of the Earth, 32: 12121220.

Mayo A.W., Muraza M. and Norbert J. (2014). The Role of Mara River Basin Wetland in Reduction of Nitrogen Load to Lake Victoria. International Journal of Water Resources and Environmental Engineering, 5(12): 659-669.

Mayo A.W., Muraza M. and Norbert J. (2018). Modelling Nitrogen Transformation and Removal in Mara Basin Wetland Upstream of Lake Victoria, Physics and Chemistry of the Earth, 105: 136-146, https://doi.org/10.1016/j.pce.2018.03. 005.

Metcalf and Eddy Inc. (2003). Wastewater Engineering: Treatment, Disposal and Reuse. McGraw Hill Ltd., New Delhi, India.

Mitsch W.J. and Gosselink J.G. (2007). Wetlands (Fourth Edition). John Wiley and Sons Inc., Hoboken.

Morrow R.J. (2009). Effects of ammonia on growth and metabolism in Tilapia, Oreochromis Niloticus. Master of Science thesis, Department of Biology Queen's University, Kingston, Ontario, Canada.

Muller M.M., Anastacio P.M., Frias A.F. and Marques A.F.J.C. (1999). Crispcrayfish Rice Integrated System of Production. Simulation of Nitrogen Dynamics. Ecological Modelling, 123: 41-52.

Muraza M. (2013). Modelling Nitrogen Transformation and Removal in Mara River Basin Wetlands. MSc Dissertation, Department of Water Resources Engineering, University of Dar es Salaam, Tanzania.

Muthuri F.M., Jones M.B. and Imbamba S.K. (1989). Primary Productivity of Papyrus (Cyperus papyrus) in a Tropical Swamp; Lake Naivasha, Kenya. Biomass, 18: 1-14.

National Water and Sewerage Corporation (2015). National Water and Sewerage
Corporation Sewer Services. Kampala, Uganda.

Novozamsky I., Houba V.J.G., Van Eck, Van Vark, W. (1983). A Novel Digestion Technique for Multielement Plant Analysis. Commun. Soil Sci. Plant Analysis, 14: 239-249.

Painter H.A. (1970). A Review of Literature on Inorganic Nitrogen Metabolism in Micro-organisms. Water Resources Journal, 4: 237-248.

Patrick W.H. and Wyatt R. (1964). Soil Nitrogen Loss as a Result of Alternate Submergence and Drying. Soil Science Society of America, 28: 647652.

Rogan W.J. and Brady M.T. (2009). Drinking water from private wells and risks to children. Pediatrics, 123(6): 1599-1605.

Senzia M.A. (2003). Modelling of Nitrogen Transformation and Removal in Horizontal Subsurface Flow Constructed Wetlands During Treatment of Domestic Wastewater. $\mathrm{PhD}$ Thesis, University of Dar es Salaam, Tanzania.

Shin K.W., Kim S., Kim J., Hwang S.D. and Kang J. (2016). Toxic effects of ammonia exposure on growth performance, hematological parameters, and plasma components in rockfish, Sebastes schlegelii, during thermal stress, Fisheries and Aquatic Sciences, 19(1): 44, https://doi.org/10.1186/s41240-0160044-6

Terer T., Gichuki N.N. and Ndiritu G.G. (2005). Role of Wetlands in Maintaining Stability of Tropical Lakes: A Case Study of River Nyando Delta in Lake Victoria Basin, Kenya. In: Odada O., Olago D.O., Ochola W., Ntiba M., Wandiga S., Gichuki N., Oyieke H. (Eds.). Proceedings of the $11^{\text {th }}$ World Lakes Conference, Nairobi, Kenya, 560-567.

Uganda National Environmental Management Authority (NEMA) (2016). The Uganda National Effluent 
Discharge Standards. Kampala, Uganda.

UNEP (2013). Water Quality of World River Basins. UNEP Environmental Library, Nairobi, Kenya.

U.S. Environmental Protection Agency (2000). Manual. Constructed Wetlands Treatment of Municipal Wastewaters. Office of Research and Development, Cincinnati, Ohio 45268.

Watebawa V. (2012). Lubigi Wetland Under Attack. Human Rights Network-Uganda, Kampala, Uganda.

Weber K.P. and Legge R.L. (2008). Pathogen removal in constructed wetlands. In: Wetlands: Ecology,
Conservation \& Restoration, Chapter 5, Russo R.E. (Ed.), Nova Science Publishers, Inc.

WHO (2015). Guidelines for Drinkingwater Quality. Volume 1, Recommendations $\left(8^{\text {th }}\right.$ Edition $)$. World Health Organization, Geneva.

Wu S., Carvalho P.N., Müller J.A., Manoj V.R. and Dong R. (2016). Sanitation in constructed wetlands: A review on the removal of human pathogens and fecal indicators. Science of The Total Environment, 541: 8-22. DOI:10.1016/j.scitotenv.2015.09.047 